\title{
Escribir la antropología: del texto al contexto
}

\section{Bruno Lutz}

Sociólogo y antropólogo miembro del Sistema Nacional de Investigadores Nivel 1 Profesor investigador del Departamento de Ciencias Sociales, Universidad Autónoma Metropolitana - Xochimilco, brunolutz01@yahoo.com.mx

Resumen

El objetivo de este trabajo es mostrar que el contexto de la escritura de las narraciones antropológicas tiene una influencia determinante sobre su clasificación como texto científico. En el análisis de obras seleccionadas de Bronislaw Malinowski, Lévi-Strauss, Marc Augé y Nigel Barley, descubrimos que el estatus y prestigio de cada uno de los autores influenciaron el destino académico de sus respectivas narrativas. Asimismo, se presentarán los resultados de la exploración de algunos de los senderos epistemológicos del saber antropológico, resaltando el peso determinante del constructo social de las condiciones de publicación.

Abstract

The purpose of this work is to show that the context of writing anthropological narrations has a determinant influence on its classification as scientific text. In the analysis of selected works of Bronislaw Malinowski, Lévi-Strauss, Marc Augé and Nigel Barley, we fund that the status and prestige of each one of these authors influenced the academic destiny of their respective narratives. Also, the results of the exploration of some of the epistemologic footpaths of the anthropological knowledge will appear, emphasizing the determining weight of social constructo of the conditions of publication.

Palabras Clave: Antropología, Autor, Etnografía, Narrativa, Texto

Keywords: Antropology; Author; Etnography; Narrative; Text

\section{Introducción}

Hay que decirlo: las palabras no son únicamente el vínculo social entre los individuos, ni tampoco la prueba exclusiva de su pertenencia al género humano, las palabras son también esta materia blanda desigualmente compartida que autoriza infinitos juegos de traducción, reinterpretación e invención. Las palabras constituyen una reserva de exterioridad la cual posibilita a una disciplina como la antropología esculpir el otro con la descripción/explicación de sus costumbres, ritos, vida cotidiana y formas de organización. El texto antropológico o etnográfico, según cómo se defina uno u otro, es una reconstrucción del universo social de un otro diferente. El objeto de la antropología es un sujeto diferente, percibido a través del prisma de una interpretación estratificada: cultural, social, geográfica y simbólicamente centrada. La diferencia es la condición de existencia de la antropología, diferencia que podemos denominar "radical" o "fractal" porque tiende a hacer del otro un ser inalcanzable para el sujeto conociente. Rebasa las fronteras del yo para marcar los límites de un yo civilizacional. Las diferencias que separan al etnógrafo del sujeto no pueden llenarse más que por el eco 
de otras diferencias más pequeñas y más sutiles. La antropologización del sujeto contiene en su seno la concepción de un ser ontológicamente diferente, diferencia misma que posibilita la constitución de un epistemé.

El texto antropológico es originariamente una "fábrica cultural": describe, analiza y afirma lo que es el otro, es decir construye un ser colectivo diferente a partir de creencias, costumbres e idioma no compartidos por el autor y los lectores. Este discurso puede verse también como el crisol de concepciones validadas en un momento y contexto dados, mediante mecanismos de legitimación científica que operan gracias a su poder demiúrgico, para discernir lo verdadero de lo falso. Al respecto Clifford (1991: 144) señala:

"Al analizar estas complejas transformaciones se debe tener en mente el hecho de que la etnografía está, desde el principio hasta el fin, atrapada en la red de escritura. Esta escritura incluye, mínimanente, una traducción de la experiencia a una forma textual. Este proceso está complicado por la acción de múltiples subjetividades y de constricciones políticas que se encuentran más allá del control del escritor. En respuesta a estas fuerzas, la escritura etnográfica pone en juego una estrategia de autoridad específica."

Precisamente, la apreciación políticamente encauzada (en sentido amplio) de las producciones científicas de la antropología ha permitido no solamente la constitución de un saber especializado sino y más profundamente, la validación de una distancia epistémica entre el autor y su producción. ${ }^{1}$ Desde mucho antes que Malinowski, con las consideraciones epistemológicas de sabios tan distintos como Herodoto, Ibn Jaldun y Bernardino de Sahún por ejemplo, la metodología era el camino para alcanzar la objetividad, mientras que los métodos eran las etapas para ir construyendo el objeto de una proto-ciencia de lo social. Esta loable búsqueda de los instrumentos intelectuales para inventar un discurso que se diferenciara del discurso mítico y del discurso metafísico, conllevó a sustituir la búsqueda de la verdad por la construcción de una veracidad discursiva. Del discurso anunciando la verdad se pasó a una verdad discursiva. Pero esta verdad discursiva no es más que un señuelo ya que la objetividad de los discursos antropológicos es ante todo una condición de posibilidad. De hecho, en un ejercicio de autorreflexión iniciado hace algunos años, se ha empezado a señalar que el texto antropológico, de cierta manera, es una ficción (Geertz, 1989).

En este ensayo partiremos de la idea de que la narrativa antropológica es ante todo un texto que conlleva, en los intersticios de su formato y difusión, subrepticiamente diseminado, el sello de su género. Los elementos que participan en esta codificación del discurso son generalmente invisibles porque constituyen una doxa preestablecida entre el autor, el editor y los lectores. Si bien existe cierta diversidad en cuanto a las narrativas etnográficas como bien lo señala Marcus $(1991),{ }^{2}$ no obstante no dejan de existir mecanismos que codifican las obras etnográficas certificándolas como tales así como los artefactos simbólicos conexos que construyen un aura de respetabilidad a su autor, anunciando el destino de sus palabras. El saber antropológico es un saber anticipado. Es un saber anticipado y patentado gracias al nombre del autor. Cuando los jóvenes etnólogos todavía "no tienen un nombre" casi todos mencionan al de sus profesores e ilustres revisores, pero cuando son antropólogos conocidos es frecuente que aparezca su único apellido. Foucault nos señala que el nombre del autor funciona para caracterizar cierto modo de ser del discurso:

"el hecho que se pueda decir "esto ha sido escrito por tal", o "tal es el autor" indica que ese discurso no es una palabra cotidiana, indiferente, una 
palabra que se va, que flota y pasa, una palabra inmediatamente consumible, sino que se trata de una palabra que debe ser recibida de un cierto modo y que debe, en una cultura dada, recibir un cierto estatus." (La traducción es mía) (Foucault 1994:798).

Un texto es catalogado como "antropológico" primero a partir de lo que lo rodea, es decir los signos de su autenticidad. Luego, es apreciado por los colegas y críticos según el grado estimado de veracidad de su contenido, según la pertinencia de su abordaje científico del tema y finalmente en función de la calidad de su prosa.

En esa tesitura, aparece fundamental el reflexionar sobre las condiciones de existencia del género etnográfico en la literatura así como sobre las reglas de posicionamiento de los textos etnográficos entre sí. Es posible concebir a la antropología como un campo en el sentido de Bourdieu (1991) - estructurado a partir de reglas formales y a menudo tácitas capaces de determinar el espacio de las acciones posibles. En este campo donde dialogan y se enfrentan entre sí múltiples escuelas, corrientes y grupos, se ha iniciado en los años ochenta una reflexión sobre dos nociones relacionadas entre sí: la "narración antropológica" y el "antropólogo como autor". A medio camino entre la preocupación epistemológica y el análisis literario, esta reflexión tenía entre sus objetivos el establecer una nueva clasificación de las obras antropológicas a partir de una revisión crítica del realismo etnológico, buscando reevaluar mutatis mutandi la posición elevada ocupada por un puñado de antropólogos consagrados. Encabezando esta empresa de transformación del campo antropológico, Clifford Geertz se ha destacado por la acuciosidad de sus comentarios pero también por el sesgo de los mismos (Clifford, 1991; Agudo, 1999).

Ahora bien, en este ensayo se plantea que el discurso antropológico, en su modalidad de producción textual, moviliza cierto tipo de mecanismos simbólicos, institucionales y comerciales. Al considerar una obra (cultural, artística, literaria, etc.) como texto, Bourdieu (1991: 62) señala que existen interpretaciones internas y explicaciones externas. En el ámbito de los comentarios de las narraciones etnográficas, es posible afirmar que siguen predominando hasta el momento interpretaciones internas: estudios de corte epistemológico, trabajos de análisis literario desde diferentes perspectivas efectuados por antropólogos, búsquedas de lógicas intertextuales, etc. Sin embargo, y porque obliga a los propios antropólogos admitir y revelas las condiciones mismas de constitución del campo antropológico, casi no hay publicaciones sobre las narraciones etnológicas desde la perspectiva de las explicaciones externas. Salvo de manera marginal y con respecto a obras de antropólogos fallecidos, se puede encontrar este tipo de análisis que privilegia las condiciones de la producción de una obra para entenderla y darla a entender.

Asimismo, nos pareció importante esbozar una hermenéutica que tome en cuenta tanto la trayectoria de los antropólogos y su posición en el campo académico en el momento de la publicación de su obra, como los elementos que rodean los textos o paratextos (prefacio, agradecimientos, dedicatoria, editorial, etc.). Más precisamente, el análisis de textos etnográficos situados en la periferia de esta disciplina, es decir textos que no entran en la categoría del realismo etnográfico, permitirá mostrar cómo, a pesar de estar al margen del género establecido, han sido considerados como "auténticamente antropológicos". Se buscará examinar determinadas obras de Malinowski, Lévi-Strauss, Marc Augé y Nigel Barley para comprender cómo fueron consideradas formando parte de la literatura antropológica. El haber seleccionado a autores de tradición anglosajona y etnólogos franceses, nos permitirá también apuntar elementos contextuales que podrían caracterizar a dos tradiciones antropológicas 
distintas ya que tiende a predominar perspectivas interpretativas culturalmente centradas.

\section{Fe y estigmas del trabajo etnográfico: Bronislaw Malinowski}

Bronislaw Malinowski es considerado por muchos como el padre fundador de la antropología social e inventor del trabajo de campo como método científico de recolección de información. Los grandes aportes de su obra maestra Los argonautas del Pacífico Occidental. Comercio y aventura entre los indígenas de Nueva Guinea Melanésica le han permitido, con justa razón, recibir elogios y cosechar honores. Al mirar más detalladamente las condiciones de realización de su trabajo de campo, el lector descubre que detrás de su prolongada estancia en los archipiélagos del extremo oriental de Melanesia, están el azar y las adversidades del destino. Una beca generosamente otorgada por uno de sus mentores, a la cual se sumó otra de la administración colonial británica (Home and Territories Department of the Commonwealth), le permitió observar in situ varias tribus aborígenes.

"He vivido en este archipiélago cerca de dos años, en el curso de tres expediciones a Nueva Guinea, lo que me ha permitido adquirir un perfecto conocimiento del idioma. Hice mi trabajo completamente solo, viviendo la mayor parte del tiempo en los poblados indígenas." (Malinowski 1995:14).

Con estas precisiones, el autor confirma la autenticidad de su expedición entre los melanesios y recalca la veracidad de la información que proporciona en su obra. ${ }^{3}$ La mención de los nombres de sus renombrados patrocinadores en los Reconocimientos confirma el carácter científico de la obra, pero es sobretodo el Prefacio de Sir James Frazer, profesor en la London School of Economics y sabio británico de inmenso prestigio, que dio al estudio de Malinowski la mejor certificación, validando Los argonautas del Pacífico Occidental como obra científica y reconociendo el valor intelectual de su autor y pupilo. Por otro lado, Malinowski, al señalar el nombre de todos los "occidentales" que lo ayudaron en un aspecto o en el otro de su investigación (bibliotecarios, funcionarios y comerciantes) reafirma la autenticidad de sus expediciones realizadas de septiembre 1914 a agosto 1915 y de octubre 1917 a julio 1918. El detallar el monto de su beca y pormenorizar los tipos de ayuda que le brindó Hancock, un comerciante de perlas, más allá del compromiso ético y humano del antropólogo hacia sus colegas occidentales, permite nombrar algunos elementos vivos, sujetos occidentales de carne y hueso, que están detrás de la obra antropológica e, indirectamente, la validan. Esta construcción del principio del libro a partir de un Prefacio firmado por un conspicuo sabio y unos Agradecimientos donde se revelan detalles prácticos relativos al estudio realizado, constituyen indudablemente eficaces mecanismos para clasificar la obra en el género antropológico y elevar a su autor a la cúspide de los científicos sociales de su época. Aunado a eso, debe señalarse que el proceso de elaboración de la metodología etnográfica sobre una base científica y con una orientación funcionalista, estuvo fuertemente influenciado por las contingencias personales que vivió el propio Malinowski: en contra de su voluntad prolongó su estancia en los archipiélagos melanésicos para no ser apresado por su nacionalidad polaca, y a pesar suyo tuvo que vivir y convivir con los aborígenes debido al recelo general de los misioneros y de los colonos.

Ahora bien, es menester apuntar que Malinowski no agradece al boy que le sirvió de intérprete, cocinero y ayudante durante sus largas estancias en las islas Trobriand, ni tampoco agradece a los aborígenes que lo ayudaron en su investigación permitiéndole, desde dejarlo invadir su territorio, hasta darle explicaciones detalladas de todo lo que 
él solicitaba. Incluso estos aborígenes intercambiaron con el antropólogo sus ídolos más sagrados por mercancías "occidentales" de poco valor. Los primitivos de Malinowski actúan y tienen creencias, pero no hablan. En los Argonautas del Pacífico occidental, los motu, mailu y kiriwinian son callados para dejar escucharse la única voz de un Malinowski fungiendo como la Pitia de los Trobriands; la obra está escrita en primera persona del singular. Es que en realidad el célebre antropólogo vivía su estancia entre los salvajes como un verdadero suplicio y buscaba por todos los medios acercarse a los occidentales para convivir con ellos. La publicación de sus Diarios nos reveló además que Bronislaw Malinowski tenía hacia los aborígenes la doble actitud del entomólogo y del colón: disecaba el lenguaje y las costumbres de los isleños con el escalpelo de la Ciencia, y trataba a los individuos de estas tribus desde el púlpito de un mercader de tercer orden. La luminosa ingeniería metodológica que Malinowski plasmó en su obra maestra distaba de ser la que él había aplicado o, mejor dicho, omitió de esta joyería intelectual, el tipo de relación humana que el antropólogo debe de tener con sus informantes, así como la influencia de los estados de ánimo del científico social en su convivencia con los salvajes. Publicados cuatro décadas después de haber sido escritos y a veinte años de su muerte, Los Diarios de Malinowski revelaron al mundo no solamente el lado oscuro de la personalidad de este eminente científico, sino, y más profundamente alumbraron la trampa del texto y el simulacro de la escritura etnográfica.

La última esposa de Malinowski, en el Prefacio de $A$ Diary in The Strict Sense of The Term, justifica la publicación póstuma del polémico diario de su cónyuge de la siguiente manera:

"...considero que cuando estamos en posesión del diario o de la autobiografía de un hombre eminente, estos "materiales" tocando su vida interior, su cotidiano y el trabajo de su pensamiento, su esfuerzo creativo, deberían de ser publicados con la deliberada intención de descubrir su personalidad, en relación con la obra realizada. (...) Llegué a la conclusión de que era más importante permitir a los futuros investigadores y lectores de las obras de antropología que escribió Malinowski descubrir su manera de vivir y de pensar durante este periodo donde nos lleva más a lo esencial de su trabajo de campo que a dejar estas breves notas en el secreto de los archivos." (La traducción es mía) (Malinowski 1985: 18-19).

El antropólogo de origen polaco había decidido dejar sus Diarios y mucho más material suyo dormir en los archivos de la London School of Economics. Pero con la polémica decisión de su viuda, se abrió un nuevo capítulo en la historia de la antropología, ya que se descubrió a un etnógrafo psicológicamente inestable, atormentado por pulsiones sexuales (el deseo imposible de satisfacerse de una mujer, de varias) y por pulsiones de muerte (morirse como depresivo adicto al cianuro, y hacer morir simbólicamente a algunas relaciones amorosas anteriores a su expedición y también a los aborígenes). Y ambas derivas psicológicas se responden cuando, por ejemplo, obsesionado por el recuerdo y las cartas de una mujer que designa por E.R.M. el trastornado padre de la antropología moderna sentencia: "Los Niggers ${ }^{4}$ no existen" (Malinowski, 1985: 182).

Sus diarios desmontan la narrativa que Malinowski construyó con esmero y paciencia en su famosa obra etnográfica. Los argonautas del Pacífico Occidental y A Diary in the Strict Sense of the Term son dos narrativas de un mismo autor, escritas a partir de la misma experiencia de trabajo de campo pero con valencias opuestas: el primero es un texto "frío", mientras el segundo es un texto que podemos denominar "caliente". El 
primero busca ser un texto científico (lo que fue una preocupación constante para Malinowski pero también para otros sabios contemporáneos suyos como Durkheim y Freud, por ejemplo); el segundo no busca nada, no tiene pretensión alguna excepto quizá la de aliviar a su autor de los tormentos que laceraban su espíritu. Así, la distancia que separa una narrativa de la otra puede ser considerada como el espacio imprescindible para una hermenéutica en contrapunto. A pesar de lo que el antropólogo funcionalista defendía, y los demás científicos sociales junto a él, la necesaria reducción del autor a una presencia diáfana para así aumentar el poder de evocación del texto y por ende el prestigio del científico narrador, a pesar y en contra de eso debe considerarse la inclusión total del autor en su texto. Lévi-Strauss es ciertamente el más conocido de los etnólogos que eligieron esta segunda vía, la vía de una etnografía autoreferenciada.

\section{La antropología como ejercicio literario: Lévi-Strauss}

Mientras Malinowski, ya profesor con prestigio internacional, daba clases en la Universidad de Yale, el joven Claude Lévi-Strauss realizaba su trabajo de campo en Brasil. Pero es solamente hasta 1955 que publicó Tristes tropiques, es decir quince años después de haber regresado del país sudamericano. De cierta forma son memorias. Lévi-Strauss comparte con el padre del funcionalismo el hecho de haber escrito en primera persona, pero, a diferencia de éste, la obra literaria y autobiográfica de Lévi-Strauss ha sido escrita para ser publicada buscando dar a conocer sus tempranas frustraciones como profesor de filosofía, el nacimiento de su vocación como etnólogo, sus expediciones en la región amazónica de Brasil, sus viajes en otras partes del mundo, y también sus reflexiones personales sobre los males de la civilización occidental y los efectos deletéreos de la modernidad. La presencia de estos dos últimos tópicos a lo largo de la obra Tristes tropiques permite vincularla tanto con la tradición de la novela filosófica ejemplifica con Zadig o el destino de Voltaire, como del pensamiento rousseauista de elogio de las virtudes del salvaje y su mundo primitivo. Así, la narración de viaje del antropólogo estructuralista intenta revivir la larga tradición del viaje filosófico que fue vigente del siglo XVI al XIX, pero al mismo tiempo el antropólogo estructuralista describe experiencias personales de su oficio con la triple distancia del tiempo, del espacio y de la autocrítica.

"iCuánto tiempo para acceder a narrar mis expediciones! " revela Lévi-Strauss (1955:9) al comienzo de su obra, insinuando de esta manera que tuvo que vencer profundas resistencias personales antes de lanzarse en esta arriesgada aventura en el género de la antropología literaria. Tristes tropiques es una narración anti-etnográfica en el sentido que revela los mecanismos de la intertextualidad del pensamiento. Dice lo que sus dos obras anteriores no decían, y al mismo tiempo anuncia el eje de reflexión de su siguiente libro La pensée sauvage (El pensamiento salvaje). Da a conocer, en primera persona, los deseos e intereses que lo habitaron hasta el momento de escribir su libro. Revela también sus frustraciones y fracasos en, por ejemplo, sus encuentros con "salvajes" que vivían todavía en un estado primitivo. El etnógrafo de las sociedades arcaicas se vuelve el etnógrafo de sí mismo, curador de sus pensamientos y crítico de las emanaciones de su propia civilización, tal como lo señala Geertz:

"Es el clásico ejemplo de libro cuyo tema es en gran parte él mismo, y cuya intención es mostrar lo que, de tratarse de una novela, tendríamos que llamar ficcionalidad..." (Geertz, 1989: 37).

Pero reconoce en otra parte que: 
"... si bien dista de ser un gran libro de antropología, o siquiera un libro especialmente bueno de antropología, es seguramente uno de los libros más bellos escritos por un antropólogo: Tristes tropiques" (Geertz, 2005: 288).

Sin llegar a considerar junto con el autor norteamericano que Tristes tropiques es un mito que debe ser analizado como un architexto, no obstante puede ser aceptada la aseveración de que varios textos se entrelazan entre sí al interior de la obra de LéviStrauss, y no solamente se yuxtaponen temas diferentes y se suman de manera contigua diversas perspectivas sino que el autor, desde la torre de su erudición, juega con los espejos del lenguaje contrastando las luces de sus experiencias etnográficas con las sombras de un Occidente depredador.

Tristes tropiques surge después de la publicación de una obra etnográfica y de otra teórica de gran alcance Las estructuras elementales del parentesco. En el Prefacio de la obra anteriormente señalada, el joven etnólogo cita a manera de agradecimiento, a ilustres pensadores sociales muy influyentes en su época: Löwie, Kroeber, Linton, Leenhardt, Koyré, Paul Rivet, Georges Davy y Alfred Métraux entre otros. En esta tradición académica de agradecer públicamente a sus profesores en la publicación de la tesis, detrás de una cortesía formal no totalmente desprovista de ética, existe la voluntad de establecer un linaje intelectual o mejor dicho de reconstruir un linaje hasta incluirse, de consolidar una solidaridad de doble sentido que permita el reconocimiento mutuo entre los profesores titulares y el nuevo doctor. En Las estructuras elementales del parentesco, aunado a la exhibición de esta prestigiosa lista de personalidades de las Ciencias Sociales, Lévi-Strauss dedica su enciclopédica investigación al conspicuo Lewis H. Morgan para:

"rendir homenaje al gran iniciador de un orden de investigaciones en el que nosotros, siguiéndolo, nos involucramos modestamente; inclinarnos, a través él, frente a esta escuela antropológica americana que fundó y que nos ha, durante cuatro años, asociado tan fraternalmente a sus trabajos y discusiones; y quizá también, intentar devolverle, en pequeña medida, el servicio que le debemos, recordándole que ha sido grande sobretodo en una época donde el escrúpulo científico y la exactitud de la observación no le parecían incompatibles con un pensamiento que se reconocía teórico sin avergonzarse y un gusto filosófico audaz." (La traducción es mía) (LéviStrauss 1967:XIII).

De esta forma, el joven etnólogo francés -tenía apenas 39 años- pronunciaba el nombre de Morgan y recordaba su memoria para justificar su teoría general del parentesco y ampararse anticipadamente de las críticas de la comunidad científica, situándose en la sombra del conspicuo sabio inglés del siglo XIX, autodeclarado su antecesor.

En la tradición clásica de la etnografía, las obras ilustres suelen tener ilustres "patrones". Precisamente, las narrativas que pueden clasificarse en el género de "antropología literaria" carecen generalmente de este aparato discursivo de enunciación de los "santos protectores" o lo tienen muy poco desarrollado. Por ejemplo, Tristes tropiques no tiene ni dedicatoria, ni agradecimientos. En el momento en el cual Lévi-Strauss publicaba este libro (1955) ya no necesitaba de mecenas intelectuales para acreditar su obra debido a que era ya un antropólogo gozando de un creciente reconocimiento y cuya carrera académica era en ascensión. "Hacerse un 
nombre nombrando a intelectuales de renombre", tal podría ser el lema de los antropólogos -y no solamente de ellos- que se inician en la vida profesional. En este sentido, el caso del joven Claude Lévi-Strauss no parece haber sido distinto del caso de los demás pensadores de su generación: tuvo que acreditarse y ser acreditado como antropólogo en sus primeros años de ejercicio de dicho oficio antes de verse posibilitado en confesarse y confesar los pecados de Occidente.

\section{La etnovela como género híbrido: Marc Augé}

Gran admirador de Lévi-Strauss (¿fue su director de tesis? ¿le dedicó su primera obra?), el antropólogo Marc Augé tiene también con la literatura una particular consideración y afección. Pero en su caso no nos entregó una obra con prosa elegante sobre el mundo o sobre el oficio del etnólogo, sino dos libros sobre los vagabundeos de su mente tomando como pretexto su paseo por los jardines de un parque céntrico de la Ciudad Luz en un caso, y un paseo en el metro parisino en el segundo. A partir de la mitad de los años ochenta, cuando franqueaba el umbral simbólico de los cincuenta años de edad, Augé tomó la decisión de convertirse en un etnólogo de proximidad, o mejor dicho, en un antropólogo de lo cotidiano. Autor ya de una decena de libros de carácter científico sobre diferentes aspectos de las sociedades de Togo y Costa de Marfil, el director de la prestigiosa EHESS (Escuela de Altos Estudios en Ciencias Sociales) amplió su tema de investigación para incluir reflexiones personales sobre lo que iba a llamar los «no-lugares», es decir estos espacios sociales que pasaron de ser espacios del público a espacios públicos. El subtítulo de Travesía por los jardines de Luxemburgo es elocuente con respecto a la perspectiva de su autor: "etnonovela de una jornada francesa considerada desde el punto de vista de las costumbres, la teoría y la felicidad". Probablemente de lejana inspiración voltairiana, este libro narra un día, el 20 de julio de 1984, vivido por Augé en un Paris de vacaciones. Si bien el antropólogo no dedica su obra a nadie, ni tampoco explicita sus fuentes de inspiración ni nombra sus mentores en un inexistente Prefacio, no obstante eligió como epígrafe la siguiente citación de Claude Lévi-Strauss "...Nunca podemos estar seguros de haber alcanzado el sentido y la función de una institución, si no podemos revivir su incidencia sobre una conciencia individual." Con esta elección, Marc Augé hace muestra de su admiración hacia el padre del estructuralismo en antropología, y con la selección del extracto anteriormente citado Marc Augé legitima su propio enfoque. El nexo simbólico que crea el autor citado en el epígrafe con el autor que lo cita, ofrece un código, una clave para comprender la obra en su conjunto (el libro de Augé publicado originalmente en 1985, no es una excepción). Aunado a esto, el nombre de LéviStrauss es el más citado de los nombres de sabios y pensadores que aparecen en la lectura de Travesía por los jardines de Luxemburgo. El lector puede tener la sensación que Augé rinde al padre de la antropología estructural un tributo por haber sido tan grande, tan genial, por haber alcanzo junto con otros pocos -todos franceses- el Olimpo de la inmortalidad. Esta veneración por los grandes hombres que hemos encontrado también en el caso de Malinowski y del propio Lévi-Strauss al inicio de su carrera respectiva, es quizá una conducta natural y un hecho social al mismo tiempo. Pero más profundamente, es posible discernir el tributo simbólico que rinden los jóvenes científicos en su tesis de doctorado y/o en la publicación de su primera obra a su director y a quienes han inspirado su trabajo académico, del tributo (la dedicatoria o el epígrafe por ejemplo) ofrecido por etnólogos con una carrera ya establecida. Ambas categorías de escritores manifiestan una herencia y un nexo, invocan una protección: los primeros, los novicios, para conjurar la suerte haciendo las debidas ofrendas simbólicas con el propósito de obtener la clemencia de los dioses y héroes de la academia; los segundos, los mayores y experimentados, cuando siguen refiriéndose a cierto tutelaje intelectual (voluntaria y unilateralmente establecido) parecen revelar 
una autonomía incompleta, una dependencia tardada y tardía con el padre. A estos antropólogos-escritores de todas edades hay que dejarles pagar su deuda -real o imaginaria- con los guardianes de la disciplina. Frente a ellos, están los autores. Lo que diferencia precisamente los escritores de los autores es que los segundos asumen su autonomía. Los autores se limitan y atreven al mismo tiempo en firmar con su único nombre, sin sentirse obligados en poner su apellido en la sombra de otro más poderoso. Los antropólogos-autores no son forzosamente más sinceros ni más intimistas en sus descripciones, pero liberan su trabajo de las ataduras académicas, convencionales y psicológicas. En el origen y la consecuencia de esta libertad pueden encontrarse el deseo de emanciparse, una independencia real y completa e incluso un egocentrismo exacerbado, pero poco importa: el asumirse como autor es lo que cuenta. En cuanto a los antropólogos-escritores, ellos requieren, por una razón o la otra, de una legitimación ex ante para seguir escribiendo y ser reconocidos como escritores. En el caso de Marc Augé, aun con todo el prestigio de su carrera académica y administrativa, y con todo el prestigio que le confieren el ser Caballero de la Legión de Honor y el ser Oficial del Orden Nacional del Mérito de las Artes y Letras, el antropólogo necesita remitirse a alguien que admira, a un autor. Pero como responsable de sus escritos, Augé firma, explicándolo en la tercera persona del singular:

"En tanto autor, el antropólogo firma. Y al firmar, avala una serie de hipótesis. Es porque firma por lo que resulta creíble, habida cuenta de que la relación con la verdad no tiene la misma naturaleza cuando se cuenta una experiencia, cuando se realiza un análisis o cuando se proponen hipótesis" (Augé, 1987a: 54).

Por su lado, los antropólogos norteamericanos Marcus y Cushman (1991: 176) defienden la misma idea cuando afirman:

"De hecho, lo que otorga la autoridad al etnógrafo y un sentido de realidad penetrante al texto, es la afirmación del escritor de que él está representando un mundo como sólo puede hacerlo alguien que lo conoce de primera mano; de esta forma se establece un nexo íntimo entre la escritura etnográfica y el trabajo de campo".

El ubicarse en la categoría de antropólogo-escritor o la de antropólogo-autor no es una cuestión de familiaridad con las palabras, ni tampoco de don para la escritura. Augé, por ejemplo, inició su carrera como profesor de Letras en un Liceo parisino en 1963 después de haber pasado la "Agregation és Lettres" ${ }^{5}$ cumpliendo de esa forma con el deseo de su progenitor. "Recuerdo de un vértigo: mi padre quería que me convirtiera en un 'literario'. Este calificativo sustantivado ('literario') ha obsesionado mi infancia y mi adolescencia" (Augé, 1987a: 169). De la literatura pasó a la etnología sin abandonar su pulpito de profesor. En Travesía por los jardines de Luxemburgo, el etnólogo indica al lector, de manera dispersa, algunas pistas de su relación con la escritura cuando, por ejemplo, dice: "El ruido sordo de la máquina de escribir de la habitación de al lado no me distrae de mi trabajo: ruido familiar, concuerda con el carácter irregular y regular a la vez de mi escritura" (Idem: 97). La escritura como un ritmo, como el ritmo de sus propios pensamientos. Augé es el antropólogo de los textos cortos, de las narraciones breves que resaltan, por su mismo formato, la fugacidad de la realidad. Fugacidad pero también complejidad de un mundo que se despliega frente a los ojos de los científicos sociales quienes se esmeran en encontrar y explicar regularidades en las relaciones entre la gente. Marc Augé distingue al etnógrafo, del etnólogo y del antropólogo, siendo este último capaz, desde una postura 
de exterioridad, no solamente de revelarse a sí mismo sino también de provocar una reacción en los otros: al explicar las creencias y conductas de los demás, los obliga en recordar su sentido primordial. De hecho, todavía para Augé, el antropólogo escribe para dar a conocer la explicación de un fragmento de realidad, transponiendo hechos, objetivando realidades. El antropólogo: demiurgo cuyo secreto descansa en su virtuosidad hermenéutica.

A partir de ese momento entran dos nuevos aspectos de la relación del etnólogo con la escritura: la ficcionalidad de la escritura antropológica -tema ampliamente tratado por Clifford Geertz y James Clifford-, y la relación del narrador con los lectores. Con respecto al primer tema, en Travesía por los jardines de Luxemburgo, Augé esboza una reflexión a partir de la publicidad de una editorial universitaria de provincia que afirma que el libro recién publicado de un antropólogo que vivió en un suburbio compartiendo la vida y los problemas de sus habitantes es "tan verídico sobre el tema que una novela de Balzac". El científico social radicado en la capital de Francia rectifica: "Si me dijera que su trabajo de etnógrafo ha sido escrito con talento y un poder de evocación tales que el lector lo lee como si fuera una novela, no me extrañaría, estaría dispuesto a creerlo" aunque el antropólogo comparte sus dudas sobre el hecho de que la obra referida pudiera tener tales cualidades, señalando que más probablemente y más limitadamente, podría ser "tan legible como una novela y casi tan serio como una monografía de etnógrafo" (Augé, 1987a: 18). De esta forma, aunque no lo desarrolla, Marc Augé plantea el dilema de la escritura antropológica en términos de capacidad de representación, es decir la forma en cómo las ideas sobre el mundo social van siendo presentadas por el escritor u autor, y de capacidad de abstracción o sea del carácter esotérico del texto prueba de su seriedad y cientificidad. A diferencia de quienes plantean que la narración etnográfica es una ficción, Augé parece defender la posición clásica de considerar al texto antropológico como un pedazo de realidad coherente, lógico y explicativo, donde no hay otro héroe que el propio escritor u autor. Pero, paradójicamente, en su "etnonovela", el africanista nunca precisa lo que es real de lo que no lo es, ni tampoco distingue las partes "duras" de su narración (la argumentación científica) de las partes "blandas" (lo ficticio y lo verosímil). Al margen de sus propias reflexiones sobre la escritura antropológica, Marc Augé nos entrega una obra cuyo único héroe es él mismo, pero simultáneamente, cuyo único objetivo argumentativo es el de seguir y alcanzar sus propios pensamientos. En Viajero subterráneo, el etnólogo sigue mezclando recuerdos y experiencias personales con una reflexión más general sobre el viajero del metro parisino. En esta narración, Augé (1987b) invita reiteradamente al lector en seguirlo por el laberíntico camino de su reflexión: "Propongo, pues, a mis lectores hacer una incursión, un pequeño rodeo por algunas páginas del Essai sur le don...", "El lector habrá de excusarme esta nueva digresión...", "El lector no ha de sorprenderse de los adjetivos que empleo aquí...". El escritor intenta dialogar con sus lectores o mejor dicho, intenta conseguir anticipadamente el beneplácito de quienes lo leen para que aprueben sus repetidas digresiones, siguiéndolo. Augé parece construir sus párrafos, sus capítulos e incluso sus libros para ser escuchado, para que sus lectores fueran oyentes al momento de identificar las palabras que escribió. Musicalidad del verbo escrito hace del antropólogo-escritor el compositor de narraciones fragmentadas.

Pero lejos de asociar sus propios textos a piezas musicales, Augé (1987a) sostiene que, en las Ciencias Sociales, existe una doble pertinencia de la relación entre una escritura y los lectores: pertinencia técnica con el objeto de estudio, y pertinencia histórica tanto en relación con el contexto local como en relación con la historia de la disciplina. De esta forma, el investigador del EHESS defiende la idea de una caracterización de los usos de la narrativa antropológica a partir de una práctica 
codificada y de un tiempo estratificado. El lector es a la vez el recipiendario del mensaje y el umbral de la comunicación escrita. El lector es un anónimo dotado de una capacidad de intelección puesta teleológica y posteriormente, al servicio del escritor u autor. Lee, interpreta, juzga. Todavía según Augé el lector moviliza recursos cognitivos y creativos inventando o mejor dicho, volviendo a establecer el nexo entre el firmante y lo firmado.

"En las obras especulativas más que en las de ficción, aun cuando en ellas las paradojas y las incertidumbres con respecto a las nociones de narrador y de autor no tienen una naturaleza fundamentalmente diferente, el texto se distingue del hombre pero el autor se acerca al texto, casi se identifica con él, al menos desde el punto de vista del lector" (Augé, 1987a: 153).

Asimismo, el antropólogo parisino sostiene que debajo de las condiciones de pertinencia de la relación entre lo narrado y los lectores, está el proceso performativo de identificación de la narración con el narrador. Trasponiendo esta aseveración en el campo de las Ciencias Sociales, puede afirmarse que el antropólogo-escritor u antropólogo-autor surge como el genio de la lámpara mágica, es decir aparece misteriosamente con la sola invocación de sus textos. Siguiendo todavía el planteamiento de Augé y rebasándolo, el desfile de las palabras hace surgir además de la identidad de su autor, su categoría de pertenencia.

Empero, el examen de la propia obra de Marc Augé Travesía por los jardines de Luxemburgo muestra que no es así. Este texto híbrido entre ficción, memoria, ensayo y diario ha sido catalogado como antropológico por razones que indudablemente rebasan su contenido. ${ }^{6}$ Dentro de éstas, debe mencionarse el epígrafe de Lévi-Strauss, el término "etnonovela" en el subtítulo, su publicación por Hachette -una de las casas editoriales más importantes de Francia- en la colección "Histoire des gens" [Historia de la gente] que forma parte de la rama Literatura de Hachette, la trayectoria de Augé como antropólogo cuyo currículo sumaba ya una docena de libros, y sobretodo por el hecho de que Augé, al momento de la publicación de ese libro, había iniciado su mandato como presidente de la escuela de ciencias sociales más reputada de Francia (EHESS). Asimismo, es posible afirmar que los factores anteriormente mencionados en la obra Travesía por los jardines de Luxemburgo contribuyeron ampliamente en catalogarla como obra antropológica.

Las fronteras entre la novela y la narración etnológica son muy tenues no solamente porque existen elementos descriptivos de corte etnográfico en muchas novelas y que, por otro lado, pueden encontrarse sesgadas interpretaciones personales en textos antropológicos que derivan en fábulas - para retomar una expresión de Foucault, sino que existe un pequeño número de etnólogos que se desempeñan también como novelistas. Marc Augé es uno de ellos con la publicación en 2005 de su novela La mère d'Arthur (La madre de Arturo), pero más ilustrativo aún es el caso del antropólogo británico Nigel Barley.

\section{El trabajo de campo como campo de experimentación: Nigel Barley}

Nigel Barley presentó su examen doctoral en lingüística sin haber empleado otro tipo de método de recolección de información que la consulta de archivos. No había efectuado trabajo de campo alguno. "En mi caso, había hecho la tesis doctoral sobre materiales publicados o manuscritos de inglés antiguo. [Sin embargo] mis examinadores (...) se sintieron obligados a alzar un dedo amonestador y advertirme que en el futuro debía circunscribir mis estudios a áreas geográficas más 
convencionales" (Barley, 1989: 21). Tal como lo reconoce no sin humor, tenía que hacer un trabajo de campo para poder formar parte por completo de la exclusiva comunidad antropológica del Reino Unido. Después de tergiversar sobre cual de las tribus más atrasadas iba a trabajar, se decidió finalmente por los Dowey de Camerún. Tenían la reputación de ser muy salvajes y hostiles hacia quienes no formaban parte de su grupo: fue eso el argumento decisivo.

Hasta aquí la situación de Barley es similar a la de muchos jóvenes antropólogos que, inclinados por voluntad propia u aconsejados por sus mentores, buscan en lo exótico/secreto/peligroso la fuente de una posible reputación en el «medio» académico. Pero muy pocos lingüistas han leído el resultado de la investigación de Nigel Barley, mientras que la narración de las inverosímiles condiciones de realización de su estancia en este pueblo de África occidental ha sido reeditada numerosas veces y traducida en varios idiomas. Su libro publicado en 1983 The Innocent Anthropologist, Notes from a Mud Hut (El antropólogo inocente, Notas desde una choza de barro) es un diario donde el antropólogo cosecha anécdotas y narra un sinfín de peripecias ocurridas durante su trabajo de campo. A diferencia de los Diarios de Malinowski en los cuales nos hundimos en el lado oscuro del personaje cuando se confronta con los "primitivos", y a diferencia también de la tercera parte de la Introducción de la obra Los nuer de Evans-Pritchard donde el autor narra en un tono trágico las circunstancias por las cuales le fue casi imposible realizar su estudio sociológico (Evans-Pritchard, 1997: 21-28), el libro de Barley destaca por su tono jocoso, irónico y humorístico. Rompiendo radicalmente con la tradición de ofrecer prefacios, dedicatorias y otros agradecimientos a sus profesores, Barley simple y sencillamente no hace nada de eso. Es más, dedica el libro a su Jeep... Este actuar irreverente alimenta su crítica del realismo etnográfico, corriente todavía dominante que predica el objetivismo sobre una base cientista. Siendo la monografía acabada el producto más emblemático de esta tradición, en contra de ella también se eleva el antropólogo británico: "Todo eso es síntoma de la intolerable hipocresía típica de los representantes de la disciplina, que debe ser combatida cada vez que se presente la ocasión. Con esta intención me propongo escribir el relato de mis propias experiencias" (Barley, 1989: 21).

Barley se emplea en desmontar la figura del etnólogo como héroe a la vez explorador y científico, desmitificar la relación con los nativos y los métodos para recolectar información (preconizando sobornar a posibles informantes y engañarlos por ejemplo), ridiculizar la posibilidad de aportar algo a la Ciencia, todo eso reintroduciendo la dimensión humana en la narración antropológica. Demasiado humano tal vez, El antropólogo inocente es un texto donde su autor se autorretrata con los rasgos de un anti-héroe que sufre las contingencias de sus encuentros con lo desconocido. No se propone describir sino escribir las experiencias que vivió, y para muchas de ellas, padeció en carne propia. Iconoclasta por un lado, hombre sincero por el otro, Nigel Barley revela el lado oscuro del trabajo de campo con el humor que posibilita la reificación de sus vivencias africanas. Quiere mostrar que la especulación intelectual está intrínsecamente relacionada con la vida cotidiana, con el mundo de los simples mortales: "...este libro puede servir para reequilibrar la balanza y demostrar a los estudiantes, y ojalá también a los no antropólogos, que la monografía acabada guarda relación con los "sangrantes pedazos" de la cruda realidad en que se basa, así como para transmitir algo de la experiencia del trabajo de campo a los que no han pasado por ella" (Barley, 1989: 21).

El antropólogo inocente es un libro para el uso de las familias, es decir para divulgar no tanto conocimientos científicos de la antropología sino más bien para dar a conocer la aleatoriedad de los procesos de recolección de información. Los objetivos de su autor 
así como su prosa hacen de esta obra, una obra marginal -en el sentido pleno del término- en el campo de la etnología. Pero esta marginalidad debe de ser relativizada y contextualizada. En efecto, Nigel Barley estaba en condiciones de producir y editar un libro de esta naturaleza: estudió Lengua modernas en la renombrada universidad de Cambridge, y luego hizo su doctorado en Antropología social en la conspicua universidad de Oxford. Ciertamente el haber cursado sus estudios superiores en las dos mejores instituciones universitarias de Inglaterra daba a Nigel Barley la posibilidad de publicar una obra irreverente como El antropólogo inocente, es decir que su cursus universitario le autorizaba en decir cosas que otros no pueden decir por carecer de los recursos simbólicos y académicos necesarios. El contenido satírico y crítico de su primer libro le era perdonado mucho más fácilmente ya que era la narración del trabajo de campo de un doctorante de Oxford. El prestigio que le daba su universidad de adscripción y el capital simbólico que había acumulado con sus estudios anteriores en Cambridge, ofrecían a Nigel Barley la posibilidad de publicar un texto en el cual decía denunciar a los guardianes del saber antropológico: de hecho, es la casa editorial del muy serio British Museum que publicó El antropólogo inocente. Asimismo, criticar al sistema desde dentro, es lo que pretendió hacer Barley desde la trinchera de su juventud. Pero, como bien lo menciona la investigadora Jociles (1997: 115):

"Una no se explica que empleen su tiempo en una labor tan fútil si no es para ingresar o reforzar su posición en los medios académicos, que configura la función que ellos mismos le atribuyen. Barley se incorporó al Museo Británico tras su primera estancia en Camerún..."

Es posible afirmar que el pre-texto, es decir las condiciones objetivas que anteceden la primera publicación de Nigel Barley deben de ser relacionadas con los efectos del texto, tanto los efectos deseados por su autor como los efectos admitidos por los lectores. El éxito comercial de su libro, excepcional para un libro de corte antropológico, le abrió la vía para escribir más, con la pluma ligera y jocosa que lo caracteriza. Casi veinte años después de haber escrito El antropólogo inocente y contar con media docena de libros publicados en los géneros de la narración antropológica y de la ficción, Barley decidió renunciar a su puesto en el British Museum para dedicarse exclusivamente a la literatura escribiendo novelas.

\section{Conclusiones}

El examen del conjunto de los elementos que rodean obras antropológicas ubicadas afuera de la categoría del realismo etnográfico, obras de Malinowski, Lévi-Strauss, Marc Augé y Nigel Barley, nos permitió ver que las narrativas que están enmarcadas en un aparato explicativo y justificativo muy desarrollado son tesis de doctorado publicadas por jóvenes investigadores (Los argonautas del Pacífico occidental, Las estructuras de las relaciones de parentesco). Éstos tienen la necesidad de respetar los cánones no-dicho de la academia como el hecho de elogiar a los aportes de sus profesores. Pero el mencionar una serie de nombres de personajes influyentes en el campo de la etnología constituye también un instrumento eficaz para atraer hacia sí la indulgencia y porque no, los favores de los representantes de la disciplina. Un paseo por los jardines del Luxemburgo, publicación de un etnólogo maduro pero quizá incierto sobre la recepción por el público de su etnovela, contiene en epígrafe una citación de Lévi-Strauss, mientras el irreverente Nigel Barley dedica su primer libro a su Jeep. En la medida en que nos alejamos del formalismo académico pero no necesariamente de la etapa de la juventud, los preliminares se reducen y los nombres de destacados antropólogos desaparecen: por ejemplo Tristes trópicos publicado cuando su autor tenía 39 años, no tiene ni dedicatoria, ni prefacio, ni epígrafe. 
Asimismo, parece que la presencia de un "paratexto" y su importancia depende de si el trabajo se inscribe o no en el género del realismo etnográfico, y depende también del capital simbólico de su autor al momento de la publicación: escribir al margen de la narrativa antropológica tradicional sin ser marginado requiere gozar de cierto prestigio. $^{7}$

De hecho, hemos considerado que frente a los textos etnológicos es posible discernir a los antropólogos-escritores de los autores, los primeros caracterizándose por mantener esta actitud reverencial hacia sus mentores y modelos académicos, mientras los segundos, liberados de las ataduras del formalismo legitimante, no usan el paratexto como un recurso legitimador. Dos maneras de concebir su propio texto y su relación con el establishment, pero también dos puntos de partida de la narración etnográfica. Al respecto, la casa editorial que publica y se encarga de difundir la obra juega un papel siempre decisivo: conservar su carácter antropológico pero logrando ampliar el círculo de los lectores, mantener la seriedad del contenido sin extremarse en tecnicismos abstrusos, subrayar la formación intelectual de su autor pero recalcando al mismo tiempo sus cualidades narrativas, etc. El caso de El antropólogo inocente editado por el British Museum se debe tal vez menos a una apuesta comercial de esta rigurosa casa editorial que al prestigio currículum de su autor. De manera general, existe un estrecho nexo entre el perfil del antropólogo-escritor o antropólogo-autor, la posición de su texto frente al realismo etnográfico, y la casa editorial.

Finalmente, si bien el análisis del tipo de texto (descriptivo, descriptivo/reflexivo, relato de viaje, ensayo, diario de campo, etc.) y el análisis de la prosa son perspectivas que ofrecen interesantes elementos para mejor comprender el contenido de las narraciones antropológicas, no obstante debe de agregarse un examen detallado de las condiciones de producción y recepción de estas obras. Precisamente, es dirigido hacia este último objetivo que dedicamos nuestros esfuerzos en el presente artículo al considerar que la narración etnográfica no es, por sí misma, ni incluyente ni totalizante. En antropología, la palabra escrita es ante todo un pensamiento callado. $\mathbf{R M}$

\section{Bibliografía}

AGUDO SÁNCHEZ, ALEJANDRO. 1999. Antropology as a kind of writing. Mimeo 6 p.

AUGE, MARC. 2005. La mère d'Arthur. Paris: Fayard.

. 1987a. Travesía por los jardines del Luxemburgo. Etnonovela de una jornada francesa considerada desde el punto de vista de las costumbres, la teoría y la felicidad. Barcelona: Gedisa.

Gedisa.

. 1987b. El viajero subterráneo. Un etnólogo en el metro. Barcelona:

BOURDIEU, PIERRE. 1994. Pour une science des œuvres, en Raisons pratiques. Sur la théorie de l'action. Paris : Seuil, pp.59-80. 1987. Homo academicus. Paris: Ed. de Minuit.

CLIFFORD, JAMES. 1991. Sobre la autoridad etnográfica, en y C. Geertz. (Coords) El surgimiento de la antropología posmoderna. Barcelona: Gedisa, pp.141170.

EVANS-PRITCHARD, E. 1997. Los nuer. Barcelona: Anagrama. 
FOUCAULT, MICHEL. 1994. Qu'est-ce qu'un auteur ?, en Paris: Gallimard. pp.789-821.

Dits et écrits T.1.

GEERTZ, CLIFFORD. 2005. El salvaje cerebral: sobre la obra de Lévi-Strauss, en La interpretación de las culturas. Barcelona: Gedisa, pp. 287-298.

. 1991. Géneros confusos. La refiguración del pensamiento social, en

Clifford, J. y (Coords) El surgimiento de la antropología posmoderna.

Barcelona: Gedisa, pp.63-77.

. 1989. El antropólogo como autor. Barcelona: Paidos.

JOCILES RUBIO, ISABEL. 1997. Nigel Barley y la investigación etnográfica, en Política y Sociedad :24, Madrid, pp. 97-120.

LÉVI-STRAUSS, CLAUDE. 1967. Les structures élémentaires de la parenté. Netherlands: Mouton \& Co.

1955. Tristes tropiques. Paris: Plon.

MALINOWSKI, BRONISLAW. 1995. Los Argonautas del Pacífico Occidental. Comercio y Aventura entre los indígenas de la Nueva Guinea Melanésica. Barcelona: Península.

. 1985. Journal d'ethnographe. Paris: Seuil.

MARCUS, GEORGE y DICK CUSHMAN. 1991. Las etnografías como textos, en Clifford, J. y C. Geertz. (Coords) El surgimiento de la antropología posmoderna. Barcelona: Gedisa, pp.171-213.

NIGEL, BARLEY. 1989. El antropólogo inocente. Barcelona: Anagrama.

RESTREPO, EDUARDO. 2006. Naturalizando privilegios: sobre la escritura y la formación antropológica, en Antípoda, Revista de Antropología y Arqueología :002, enero-junio, Universidad de los Andes, Bogota, pp.91-111.

\section{Notas}

${ }^{1}$ Con respecto a la situación de la antropología colombiana véase Restrepo (2006).

2 "Tal diversidad existe porque en una circunstancia histórica en la que las formas convencionales no se adecuan al planteamiento de los problemas etnográficos, la creatividad es no sólo requerida, sino particularmente alentada. Mientras las etnografías estándar se siguen produciendo continuamente, se ofrecen considerables recompensas (tanto en grado de interés editorial como en respuesta crítica positiva) a los etnógrafos que ofrezcan sus trabajos expresados en forma más personales y novedosamente estructuradas" (Marcus et al., 1991: 172).

3 Debe agregarse que en la primera edición de la obra maestra de Malinowski, insertó 66 láminas fotográficas donde él aparece al lado de los isleños. Esta construcción del lenguaje narrativo fue estudiado por Stocking (citado por Clifford, 1991: 148).

${ }^{4}$ Niggers es un término peyorativo empleado por los colonos británicos para designar a las personas negras.

${ }^{5}$ Agregation és Lettres, es un título obtenido después de haber presentado y pasado un difícil concurso a nivel nacional. Otorga a su poseedor un estatus elevado dentro del cuerpo docente, permitiéndole impartir clases en los mejores liceos e instituciones de enseñanza superior en Francia.

${ }^{6}$ Con respecto a la obra literaria de Lévi-Strauss, Clifford Geertz señala también estar en presencia de varios géneros fundidos en uno solo cuando escribe: "el libro es una combinación de autobiografía, de narración de

Revista Mad. N 19, Septiembre de 2008. Departamento de Antropología. Universidad de Chile http://www.revistamad.uchile.cl/19/Lutz_01.pdf 
un viajero, de tratado filosófico, de informe etnográfico, de historia colonial y de mito profético" (Geertz, 2005: 289).

7 Bourdieu (1991: 71) lo explica así: "...cada autor, como alguien que ocupa una posición en el espacio, es decir un campo de fuerzas (irreducible a un simple agregado de puntos materiales) que es también un campo de luchas apuntando a conservar o transformar el campo de fuerzas, existe y subsiste solamente bajo las coacciones estructurantes del campo (por ejemplo, las relaciones objetivas que se establecen entre los géneros); pero también que afirma la distancia diferencial que es constitutiva de su posición, su punto de vista, entendido como una vista desde un punto, tomando una de las posiciones estéticas posibles, actualmente o virtualmente, en el campo de los posibles ( $y$ asimismo opinando sobre otras opiniones)" (la traducción es mía). 